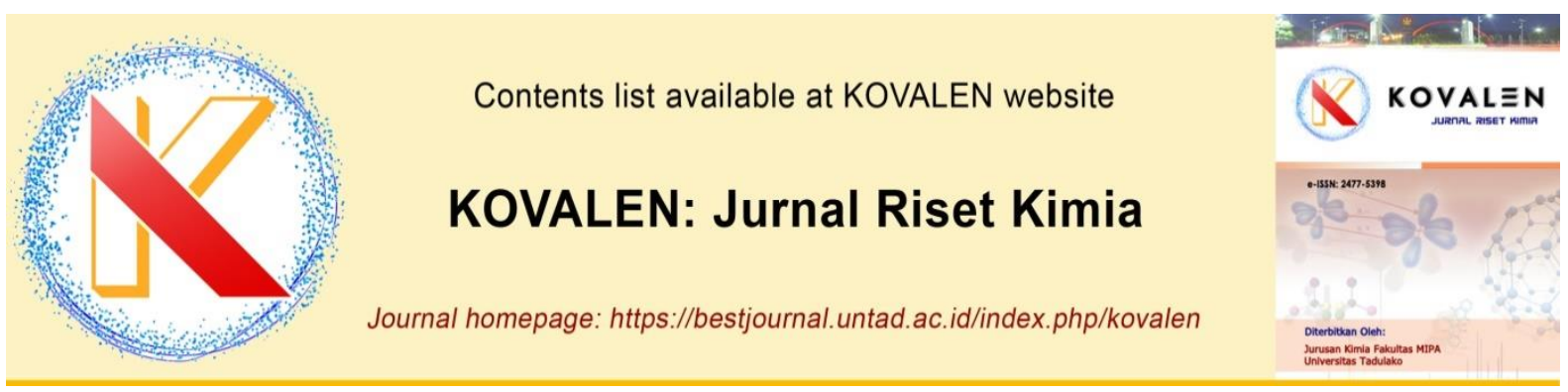

\title{
Studi Perbandingan Aktivitas Antioksidan Xantofil dan Karoten Kapang Oncm Merah pada Berbagai Waktu Inkubasi
}

\section{[Comparison Study of Antioxidant Activity of Xanthophyll and Carotene from Red Oncom Mold In Various Incubation Times]}

\author{
Sriwulan Indriani Pea*, Khairuddin, Prismawiryanti \\ 1) Jurusan Kimia Fakultas Matematika dan Ilmu Pengetahuan Alam Universitas Tadulako \\ Jl. Soekarno-Hatta Km.9, Kampus Bumi Tadulako, Palu, Indonesia \\ ${ }^{\star}$ Coresponding Author: sriwulanpea.mipakimia@gmail.com
}

\begin{abstract}
Research on a comparative study of antioxidant activity of xanthophyll and carotenoids from red oncom, mold in various incubation times has been studied. This study aims to determine the antioxidant activity of xanthophyll and carotene at various incubation times of red oncom cultured in corn cob medium. This study used a Completely Randomized Design (CRD) at variations in incubation time: 2, 3, 4, 5, 6, and 7 days. The results showed that the best antioxidant activity of xanthophyll and carotene was on the second day with antioxidant activity of $82.27 \%$ and $65.80 \%$, respectively.
\end{abstract}

Keywords: antioxidant activity, xanthophyll, carotene, carotenoids, red oncom

ABSTRAK. Telah dilakukan penelitian tentang studi perbandingan aktifitas antioksidan xantofil dan karoten karotenoid kapang oncom merah pada berbagai waktu inkubasi. Penelitian ini bertujuan untuk mengetahui aktifitas antioksidan xantofil dan karoten pada berbagai waktu inkubasi kapang oncom merah pada medium tongkol jagung. Penelitian ini menggunakan Rancangan Acak Lengkap (RAL) pada variasi waktu inkubasi: 2; 3; 4; 5; 6; dan 7 hari. Hasil penelitian menunjukan bahwa aktifitas antioksidan tertinggi dari xantofil dan karoten yaitu pada hari kedua dengan aktifitas antioksidan masing-masing $82,27 \%$ untuk xantofil dan $65,80 \%$ untuk karoten.

Kata Kunci: aktvitas antioksidan,xantofil,karoten, karotenoid, oncom merah.

Riwayat artikel: Diterima 18 Desember 2018, Disetujui 29 Agustus 2020

Cara sitasi: Pea, S.I., Khairuddin., \& Prismawiryant. (2020). Studi Perbandingan Aktivitas Antioksidan Xantofil dan Karoten Kapang Oncm Merah pada Berbagai Waktu Inkubasi. KOVALEN: Jurnal Riset Kimia, 6(2): 152-157.

DOI: https://doi.org/10.22487/kovalen.2020.v6.i2.11547

\section{LATAR BELAKANG}

Penggunaan senyawa antioksidan saat ini semakin berkembang pesat, baik untuk makanan maupun untuk pengobatan, seiring dengan bertambahnya pengetahuan tentang aktivitas radikal bebas terhadap beberapa penyakit degeneratif seperti penyakit jantung dan kanker (Boer, 2000). Tubuh manusia tidak mempunyai cadangan antioksidan dalam jumlah berlebih, sehingga jika terjadi paparan radikal 
$\begin{array}{lrr}\text { berlebih maka } & \text { tubuh } & \text { membutuhkan } \\ \text { antioksidan } & \text { eksogen. } & \text { Adanya }\end{array}$ kekhawatiran terhadap efek samping antioksidan sintetik menyebabkan antioksidan alami menjadi alternatif yang sangat dibutuhkan (Rohdiana, 2001).

Salah satu sumber antioksidan alami adalah oncom merah. Oncom merupakan salah satu produk fermentasi makanan khas Jawa yang menggunakan substrat bungkil kacang tanah atau ampas tahu yang diinokulasi dengan spora kapang oncom merah, yaitu spesies kapang yang berkembang biak secara generatif.

Salah satu spesies Neurospora yang banyak di teliti dan di pelajari sifat-sifatnya adalah Neurospora crassa. Menurut Ninet \& Renaud (1979), Neurospora crassa memproduksi pigmen karotenoid secara intraseluler yang tersimpan dalam konidia yang menyebabkan terbentuknya warna jingga. Menurut Mappiratu (1990) karotenoid terdiri atas $5 \%$ xantofil, dan $95 \%$ karoten (62\% merupakan betakaroten, 29\% alfa karoten, dan $4 \%$ gama karoten).

Sebagai pigmen yang melimpah di alam , karotenoid juga memiliki manfaat bagi kehidupan manusia, terutama sebagai sumber vitamin A, pewarna makanan, penambah sel darah merah, meningkatkan imunitas tubuh, pengganti sel-sel yang rusak, antibakteri, serta sebagai antioksidan (Ndiha \& Limantara, 2009).

Produksi karotenoid kapang oncom merah (Neurospora sp) telah dilaporkan oleh beberapa peneliti (Gusdinar et al., 2011; Mappiratu, 1990; Pahlevi et al., 2008; Purnamasari et al., 2013). Akan tetapi penelitian tersebut belum melakukan kajian tentang aktifitas antioksidan komposisi fraksi kelompok karotenoid (karoten dan xantofil) yang diproduksi kapang oncom merah relatif terhadap waktu inkubasi.

\section{METODE PENELITIAN}

\section{Bahan dan Peralatan}

Bahan utama yang digunakan dalam penelitian adalah tongkol jagung muda, inokulum kapang oncom merah bentuk bubuk, larutan campuran aseton/heksana (2:1), etanol.

Peralatan yang digunakan dalam penelitian ini adalah kukusan, kuas, alat gelas laboratorium, timbangan, rotary vakum evaporator, kuvet, spektofotometri UV-Vis PerkinElmer L850, FTIR (Fourier Tansform Infrared Spectroscopy) Brucker.

\section{Prosedur Penelitian}

\section{Produksi spora kapang oncom merah pada limbah tongkol jagung}

Tongkol jagung muda yang diperoleh dari Pasar Inpres Manonda Kota Palu dipilih kemudian disterilkan dengan cara direbus selama kurang lebih 1 jam. Tongkol jagung yang telah direbus disimpan pada rak diatas wadah tampi, dan diinokulasi dengan inokulum kapang oncom merah. Waktu inkubasi yang digunakan yaitu bervariasi dari hari kedua sampai hari ketujuh. Untuk menjaga kelembaban, nampan ditutup dengan plastik. Pada hari kedua, ketiga, keempat, kelima, keenam, dan ketujuh, dilakukan pemanenan spora menggunakan kuas (Nurakhirawati et al., 2016).

\section{Ekstraksi senyawa antioksidan dari konidia kapang oncom merah}

Ekstraksi antioksidan xantofil dari konidia kapang oncom merah dilakukan dengan metode maserasi menggunakan pelarut etanol, dengan cara menimbang konidia kapang oncom merah sebanyak 2 gram kemudian dilarutkan dengan $50 \mathrm{~mL}$ etanol $96 \%$ dikocok selama 30 menit lalu disaring, perlakuan diulang sebanyak 2 kali. Hasil ekstraksi ditepatkan volumenya hingga $100 \mathrm{~mL}$. Ekstrak xantofil selanjutnya dianalisis 
dengan spektrfotometer Uv-Vis dan FTIR. Residu yang di peroleh dikering anginkan dan setelah itu dilakukan ekstrasi karoten dari konidia kapang oncom merah menggunakan pelarut campuran aseton heksan 2:1 (v/v) dengan cara yang sama (Nurakhirawati et al., 2016).

\section{Analisis aktivitas antioksidan dengan metode DPPH}

Ekstrak pekat sampel ditentukan aktivitas antioksidannya menggunakan metode DPPH (modifikasi metode yang digunakan Amar et al., 2018). Sebanyak $25 \mathrm{mg}$ sampel dimasukkan ke dalam labu ukur $25 \mathrm{ml}$, kemudian ditepatkan dengan pelarut etanol sehingga didapatkan konsentrasi larutan 1000 ppm. Kemudian dilakukan pengenceran untuk mendapatkan larutan 200 ppm. Larutan yang telah dibuat dipipet sebanyak $2 \mathrm{ml}$ dan ditambahkan dengan

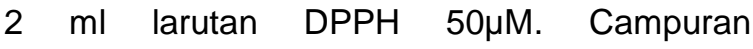
dihomogenkan dan dibiarkan selama 30 menit dalam tempat gelap. Kemudian diukur serapannya pada panjang gelombang $517 \mathrm{~nm}$. Pengujian juga dilakukan terhadap larutan DPPH, nilai absorbansi yang diperoleh digunakan untuk menentukan \% inhibisi menggunakan persamaan berikut:

$$
\% \text { inhibisi }=\frac{\text { abs. kontrol }- \text { abs. sampel }}{\text { abs. kontrol }} \times 100 \%
$$

Keterangan:

Abs. Kontrol = Absorban DPPH $50 \mu \mathrm{M}$

Abs. Sampel $=$ Absorbansi Sampel Uji

\section{HASIL DAN PEMBAHASAN}

\section{Ekstrak Senyawa Xantofil dan Karoten Kapang Oncom Merah}

Ekstraksi senyawa antioksidan dari konidia kapang oncom merah pada penelitian ini dilakukan dengan metode maserasi. Ekstrak yang diperoleh dipisahkan pelarutnya menggunakan rotari vakum evaporator dan diperoleh ekstrak pekat berwarna orange.

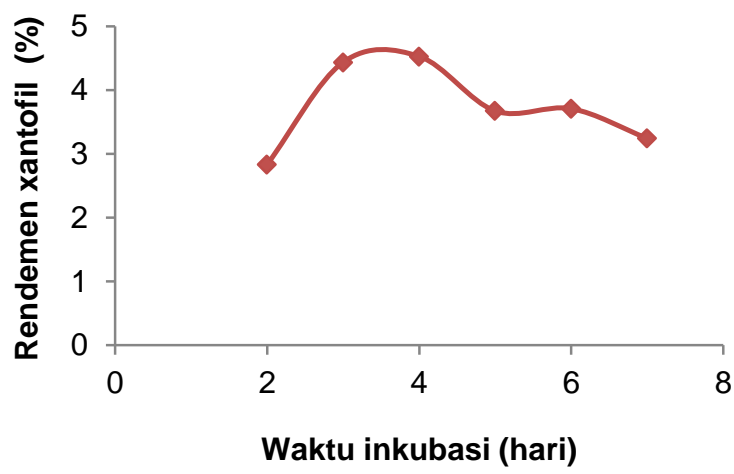

Gambar 1. Rendemen xantofil pada berbagai waktu inkubasi

Terjadi kenaikan rendemen xantofil pada hari ke-2 sampai hari ke-4, namun terjadi penurunan pada hari ke 5,6 , dan hari ke 7 (Gambar 1). Penurunan rendemen ini terjadi di duga karena nutrisi yang diperlukan oleh kapang mulai berkurang, sehingga terjadi kematian sel. Widjoyo (2008) dalam Nurakhirawati et al. (2016) mengungkapkan bahwa kematian kapang disebabkan oleh nutrisi yang ada pada media dan energi cadangan di dalam sel sudah habis. Kecepatan kematian di pengaruhi oleh kondisi nutrisi, lingkungan dan kondisi jasad renik.

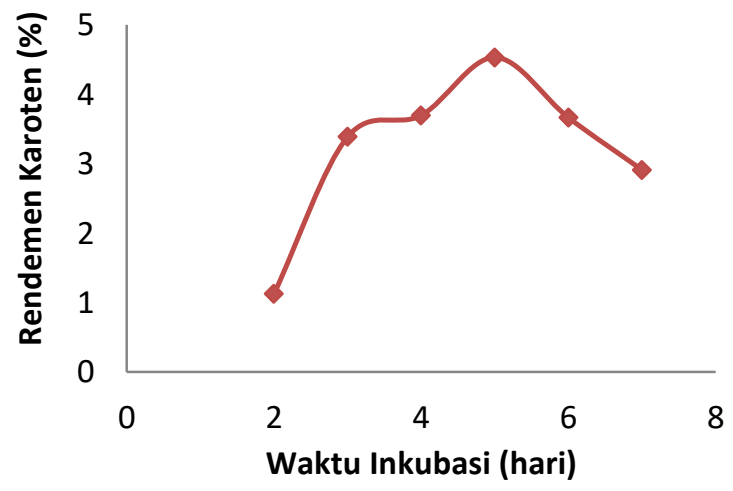

Gambar 2. Rendemen karoten pada berbagai waktu inkubasi

Rendemen karoten yang dihasilkan mengalami kenaikan yang cukup signifikan setiap harinya. Namun mengalami penurunan mulai pada hari ke 6 hingga hari ke 7 (Gambar 
2). Sama halnya dengan xantofil penurunan rendemen ini terjadi diduga oleh nutrien yang diperlukan oleh kapang mulai berkurang sehingga terjadi kematian sel. Menurut Wainright dan McVeigh (1967) dalam Indarto (2008) fase statis pertumbuhan Neurospora crassa terjadi pada hari kelima sampai hari ketujuh inkubasi.

\section{Hasil Identifikasi Ekstrak Xantofil dan Karoten Menggunakan Spektrofotometer UV-Vis}

Nilai panjang gelombang xantofil adalah 464 nm (Gambar 3), sedangkan karoten 493 nm (Gambar 4). Hampir semua senyawa karotenoid terletak pada panjang gelombang maksimum 400 - 500nm (Susilowati, 2008).

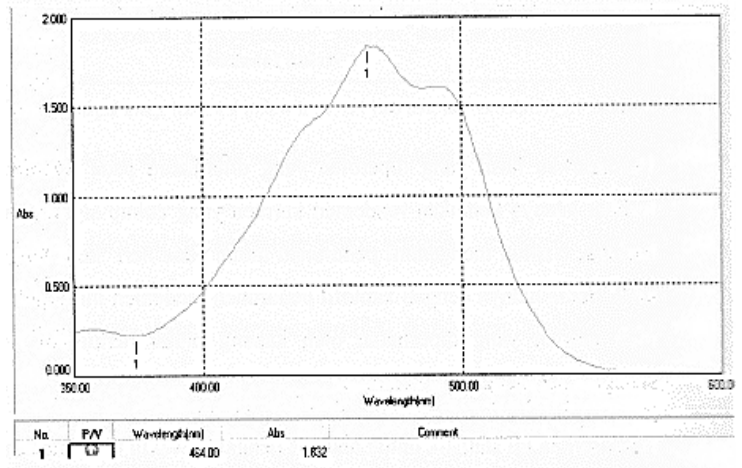

Gambar 3. Spektrum UV-Vis senyawa xantofil

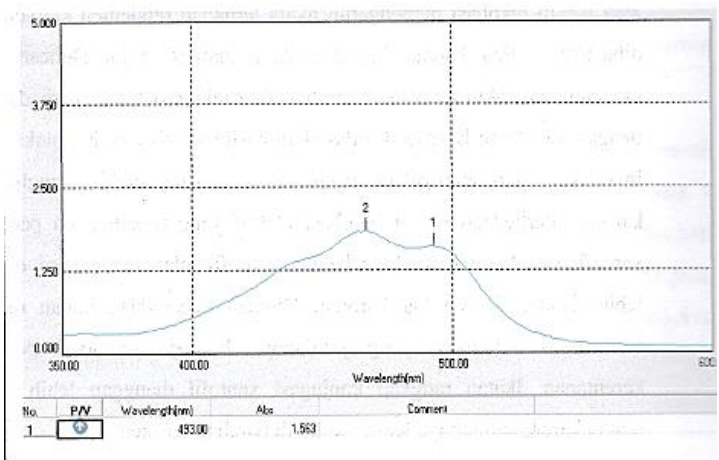

Gambar 4. Spektrum UV-Vis senyawa karoten

Dalam penelitian Hujaya (2008) memperoleh nilai panjang gelombang maksimum xantofil $(444 \mathrm{~nm})$ dan karoten (450 $\mathrm{nm}$ ) yang terlihat tidak berbeda jauh namun tetap dapat dipastikan bahwa kedua senyawa tersebut berbeda. Hal ini dapat dilihat dari perbedaan bentuk kurva, dimana kurva serapan xantofil cenderung memiliki puncak yang tajam, sementara karoten memiliki serapan yang tidak setajam xantofil. Sehingga dapat dikatakan bahwa spektrum UV-Vis dalam penelitian ini bersesuaian dengan literatur.

\section{Hasil Identifikasi Ekstrak Xantofil dan Karoten Menggunakan Spektrofotometer FTIR}

Identifikasi ekstrak xantofil dan karoten dilakukan dengan menggunakan spektrofotometer infra merah (FTIR), dengan rentang bilangan gelombang yang digunakan $4500-500 \mathrm{~cm}^{-1}$. Dari hasil yang diperoleh secara keseluruhan spektrum yang terlihat antara xantofil dan karoten dapat dikatakan tidak berbeda jauh, hanya terdapat perbedaan pada bilangan gelombangnya saja (Tabel 1 dan 2).

Tabel 1. Puncak - puncak serapan FTIR xantofil

\begin{tabular}{ccc}
\hline $\begin{array}{c}\text { Vibrasi } \\
\text { Gugus } \\
\text { Fungsi }\end{array}$ & $\begin{array}{c}\text { Puncak } \\
\text { Serapan } \\
\left(\mathrm{cm}^{-1}\right)\end{array}$ & $\begin{array}{c}\text { Penelitian } \\
\text { Pembanding }\left(\mathrm{cm}^{-1)}\right.\end{array}$ \\
\hline $\mathrm{O}-\mathrm{H}$ & 3352,28 & 3427,51 \\
$\mathrm{CH}$ & 2931,80 & $2918,30-2850,79$ \\
$\mathrm{C}=\mathrm{O}$ & 1739,79 & 1718,58 \\
$\mathrm{C}=\mathrm{C}$ & 1633,71 & 1649,02 \\
$\mathrm{CH}_{2}$ & 1460,11 & 1451,33 \\
$\mathrm{CH}_{\text {Alifatik }}$ & 1382,92 & 1375,25 dan \\
& 1226,73 & 1460,11 \\
& 1145,72 & 1261,45 dan \\
$\mathrm{C}-\mathrm{O}$ & 1085,92 & 1128,36 \\
& 1045,42 & \\
& 1028,06 & \\
$\mathrm{C}-\mathrm{H}$ & 993,34 & \\
Alkena & 933,55 & \\
keluar & 839,03 & \\
bidang & 802,39 & \\
\hline
\end{tabular}


Tabel 2. Puncak - puncak serapan FTR senyawa karoten

\begin{tabular}{|c|c|c|}
\hline $\begin{array}{l}\text { Vibrasi } \\
\text { Gugus } \\
\text { Fungsi }\end{array}$ & $\begin{array}{c}\text { Puncak } \\
\text { Serapan }\left(\mathrm{cm}^{-1}\right)\end{array}$ & $\begin{array}{c}\text { Penelitian } \\
\text { Pembanding } \\
\left(\mathrm{cm}^{-1}\right)\end{array}$ \\
\hline $\mathrm{O}-\mathrm{H}$ & 3414,00 & 3427,51 \\
\hline $\mathrm{CH}$ & $\begin{array}{l}2924,09 \\
2854,65\end{array}$ & $\begin{array}{c}2918,30- \\
2850,79\end{array}$ \\
\hline $\mathrm{C}=\mathrm{O}$ & 1722,43 & 1718,58 \\
\hline $\mathrm{C}=\mathrm{C}$ & $\begin{array}{l}1654,92 \\
1543,05\end{array}$ & 1649,02 \\
\hline $\mathrm{CH}_{2}$ & 1460,11 & 1451,33 \\
\hline $\mathrm{CH}_{\text {Alifatik }}$ & 1379,10 & $\begin{array}{c}1375,25 \text { dan } \\
1460,11\end{array}$ \\
\hline C-O & $\begin{array}{l}1379,10 \\
1234,44 \\
1080,14 \\
1041,56\end{array}$ & $\begin{array}{c}1261,45 \text { dan } \\
1128,36\end{array}$ \\
\hline
\end{tabular}

Dari hasil spectrum FTIR karoten terlihat adanya puncak $\mathrm{O}-\mathrm{H}$ (Tabel 2) yang tidak diharapkan karena karoten seharusnya merupakan senyawa pigmen yang hanya dibentuk oleh atom karbon dan oksigen. Karoten yang teroksidasi tidak lagi disebut karoten melainkan xantofil. Adanya puncak $\mathrm{O}-\mathrm{H}$ diduga disebabkan oleh keberadaan air dari pelarut dan sampel yang mana dalam penelitian ini tidak dilakukan proses penghilangan air tersebut.

\section{Perbandingan Aktivitas Antioksidan Xantofil dan Karoten}

Aktivitas antioksidan santofil dan karoten dilakukan menggunakan metode DPPH dengan Spektrofotometri UV-Vis pada panjang gelombang $517 \mathrm{~nm}$. Metode DPPH merupakan metode pengukuran aktifitas antioksidan yang cukup sederhana, cepat, serta tidak membutuhkan banyak reagen seperti halnya pada metode lain.

Potensi aktivitas antioksidan senyawa xantofil dan karoten dianalisis berdasarkan prinsip penangkapan hidrogen dari antioksidan oleh radikal bebas difenil pikril hidrazil (DPPH), saat terjadi penangkap radikal bebas, elektron menjadi berpasangan sehingga terjadi penghilangan warna (Sunarni, 2005).

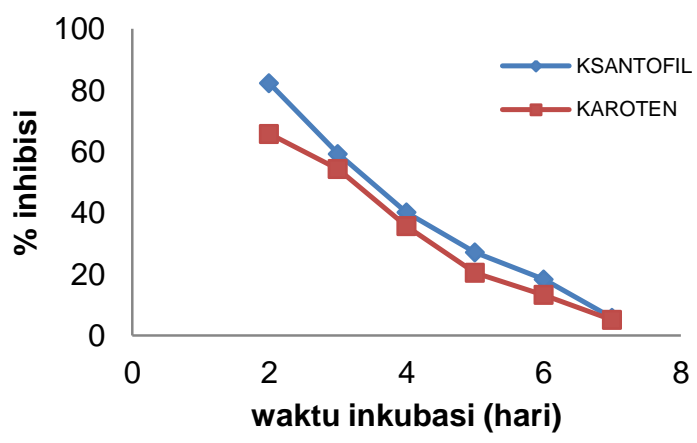

Gambar 5. Perbandingan aktifitas antioksidan xantofil dan karoten pada berbagai waktu inkubasi

Hasil penelitian menunjukkan adanya penurunan aktivitas antioksidan xantofil dan karoten dari hari ke 2 sampai hari ke 7 (Gambar 5). Penurunan aktivitas antioksidan tersebut diikuti oleh kenaikan nilai absorbansi dimana ketika nilai absorbansi naik maka \% inhibisi akan menurun yang berarti aktifitas antioksidannya juga menurun dan sebaliknya. Dimana Aktifitas antioksidan tertinggi dari xantofil dan karoten kapang oncom merah diperoleh pada waktu inkubasi hari kedua dengan aktifitas antioksidan $82,27 \%$ untuk xantofil dan $65,80 \%$ untuk karoten, dan mulai menurun dari hari ketiga sampai hari ke 7 (Gambar 5). Hal tersebut diduga disebabkan karena penyimpanan yang terbuka selama masa inkubasi, pengerigan bahan, atau bisa juga karena proses ekstraksi.

Menurut Pokorny et al. (2001) terdapat beberapa faktor-faktor yang mempengaruhi aktivitas antioksidan, yaitu pengeringan bahan, pengecilan ukuran bahan, dan proses ekstraksi. Faktor tekanan oksigen yang tinggi, luas kontak dengan oksigen, pemanasan juga dapat menyebabkan peningkatan terjadinya proses inisiasi dan propagasi sehingga menurunkan aktivitas antioksidan, akhirnya semakin lama waktu inkubasi semakin banyak pula komponen 
xantofil dan karoten yang rusak yang mempengaruhi aktifitas antioksidannya.

\section{KESIMPULAN}

Berdasarkan hasil yang diperoleh maka dapat disimpulkan bahwa: aktifitas antioksidan tertinggi dari xantofil dan karoten kapang oncom merah diperoleh pada waktu inkubasi hari kedua dengan aktifitas antioksidan 82,27\% untuk xantofil dan $65,80 \%$ untuk karoten

\section{DAFTAR PUSTAKA}

Amar, A. A., Bahri, S., \& Mappiratu, M. (2018). Aktivitas Antioksidan Mikrokapsul Ekstrak Etanol Kapang Oncom Merah (Neurospora sp). KOVALEN: Jurnal Riset Kimia, 4(2): 145-151. https://doi.org/10.22487/kovalen.2018.v 4.i2.11740

Boer, Y. (2000). Uji Aktivitas Antioksidan Ekstrak Kulit Buah Kandis (Gracinia parvifolia Miq). Jurnal Matematika Dan IPA, 1(1): 26-33.

Gusdinar, T., Singgih, M., Priatni, S., Sukmawati, A., \& Suciati, T. (2011). Enkapsulasi Dan Stabilitas Pigmen Karotenoid Dari Neurospora intermedia $\mathrm{N}-1$ (Encapsulation and the Stability of Carotenoids from Neurospora intermedia N-1). Jurnal Manusia dan Lingkungan, 18(3): 206-211. https://doi.org/10.22146/jml.18443

Hujaya, S. (2008). Isolasi Pigmen Klorofil, Karoten, dan Xantofil dari Limbah Alga di Area Budi Daya Ikan Bojongsoang [Skripsi]. ITB, Bandung.

Indarto, A. (2008). Pengaruh Waktu Inkubasi Terhadap Kandungan Karoten Dari Kapang Oncom Merah Pada Limbah Tongkol Jagung. [Skripsi]. Universitas Tadulako, Palu.

Mappiratu. (1990). Produksi Beta Karoten pada Limbah Cair Tapioka Dengan Kapang Oncom Merah [Tesis]. Institut Pertanian Bogor, Bogor.

Ndiha, B., \& Limantara, L. (2009). Karotenoid Pada Bahan Makanan. Prosiding
Seminar Nasional Biologi, Lingkungan Dan Pembelajarannya., Jurdik Biologi FMIPA Universitas Negeri Yogyakarta, hlm. 75-84.

Ninet, L., \& Renaud, J. (1979). Microbial Technology. Academic Press. Inc., New York.

Nurakhirawati, N., Aneke, H., \& Bahri, S. (2016). Kajian Retensi Karoten Kapang Oncom Merah dari Tongkol Jagung Selama Pengolahan dan Penyimpanan Mie Instan Fungsional. KOVALEN: Jurnal Riset Kimia, 2(2). http://jurnal.untad.ac.id/jurnal/index.php/ kovalen/article/view/6722

Pahlevi, Y., Estianti, T., \& Saparianti, E. (2008). Mikroenkapsulasi Ekstrak Karoten dari Kapang Oncom Merah (Neorospora sp) Dengan Bahan Penyalut Berbasis Protein Menggunakan Metode Pengeringan Semprot. Jurnal Teknologi Pertanian, 9(1): 31-39.

Pokorny, J., Yanishlieva, N., \& Gordon, M. (2001). Preparation of Natural Antioxidant, in Antioxidants in Food: Practical Applications (1st ed.). CRC Press, Cambridge.

Purnamasari, N., Adriani, M., \& Kawiji. (2013). Pengaruh Jenis Pelarut dan Variasi Suhu Pengering Spray Dryer Terhadap Kadar Karotenoid Kapang Oncom Merah (Neurospora sp). Jurnal Teknosains Pangan, 2(1): 107-114.

Rohdiana, D. (2001). Aktivitas Daya Tangkap Radikal Polifenol dalam Daun Teh. Majalah Jurnal Indonesia, 12(1): 53-58.

Sunarni, T. (2005). Aktivitas Antioksidan Penangkap Radikal Bebas Beberapa kecambah dari Biji Tanaman Familia Papilionaceae. Jurnal Farmasi Indonesia, 2: 53-61.

Susilowati. (2008). Isolasi dan Identifikasi Senyawa Karotenoid dari Cabai Merah (Capasicum Annuum Linn). [Skripsi]. Universitas Islam Negeri (UIN), Malang. 